This document is the accepted manuscript version of the following article: Berens, M. J., Hofstetter, T. B., Bolotin, J., \& Arnold, W. A. (2020). Assessment of 2,4-dinitroanisole transformation using compound-specific isotope analysis after in situ chemical reduction of iron oxides. Environmental Science and Technology, 54(9), 5520-5531. https://doi.org/10.1021/acs.est.9b07616

\title{
Assessment of 2,4-dinitroanisole transformation
}

11 *Corresponding author: William A. Arnold; Phone: 612-625-8582; e-mail: arnol032@umn.edu

14 Ferrous iron-bearing minerals are important reductants in the contaminated subsurface but their

15 availability for the reduction of anthropogenic pollutants is often limited by competition with other

16 electron acceptors including microorganisms and poor accessibility to $\mathrm{Fe}(\mathrm{II})$ in complex 
17 hydrogeologic settings. The supply of external electron donors through in situ chemical reduction

18 (ISCR) has been proposed as one remediation approach but the quantification of pollutant

19 transformation is complicated by the perturbations introduced to the subsurface by ISCR. Here,

20 we evaluate the application of compound specific isotope analysis (CSIA) for monitoring the

21 reduction of 2,4-dinitroanisole (DNAN), a component of insensitive munitions formulations, by

22 mineral-bound $\mathrm{Fe}(\mathrm{II})$ generated through ISCR of subsurface material from two field sites. Electron

23 balances from laboratory experiments in batch and column reactors showed that $3.6 \%$ to $11 \%$ of

24 the total Fe in the sediments was available for the reduction of DNAN and its partially reduced

25 intermediates after dithionite treatment. The extent of DNAN reduction was successfully

26 quantified from its $\mathrm{N}$ isotope fractionation measured in the column effluent based on the derivation

27 of a $\mathrm{N}$ isotope enrichment factor, $\varepsilon_{\mathrm{N}}$, derived from a comprehensive series of isotope fractionation

28 experiments with numerous $\mathrm{Fe}(\mathrm{II})$-bearing minerals as well as dithionite-reduced subsurface

29 materials. Our observations illustrate the utility of CSIA as a robust approach to evaluate the 30 success of in situ remediation through abiotic contaminant reduction.

32 INTRODUCTION

33 Ferrous iron (Fe(II)) associated with Fe-bearing minerals (e.g., iron (oxyhydr)oxides, clays,

34 sulfide minerals) is an important reductant of many subsurface pollutants. ${ }^{1-6}$ Despite an abundance

35 of $\mathrm{Fe}(\mathrm{II})$ in the anoxic subsurface, pollutant reduction is often limited through competition with

36 other potential electron acceptors and restricted pollutant transport and accessibility to reactive

37 Fe(II)-bearing minerals in response to local hydrogeologic conditions. Several approaches have

38 been evaluated to enhance the availability of reactive $\mathrm{Fe}(\mathrm{II})$ including biostimulation, ${ }^{7,8}$

39 bioaugmentation, ${ }^{9,10}$ additions of external electron donors (i.e., in situ chemical reduction; ISCR) 
40 including dithionite, ${ }^{11,12}$ polysulfides, ${ }^{13}$ and (sulfidized) ZVI, ${ }^{14,15}$ and combinations thereof. ${ }^{16}$ To

41 date, several of these strategies have been successfully applied to a number of environmental

42 contaminants including heavy metals ${ }^{12,17,18}$ and chlorinated solvents..$^{14,19,20}$

43 One major challenge when applying an in situ (bio)remediation technique is providing a reliable

44 evaluation of performance; it is difficult to quantify the amount of transformed contaminants from

45 concentration measurements alone. ${ }^{21-23}$ For example, the need to (repeatedly) inject aqueous

46 solutions containing electron donors into the subsurface introduces perturbations that may lead to

47 pollutant dilution without degradation. Moreover, reduction of $\mathrm{Fe}(\mathrm{III})$ induces partial reductive

48 dissolution and transformation of reactive $\mathrm{Fe}$ minerals and could mobilize solid-bound

49 contaminants..$^{17,24-26}$

50 Compound specific isotope analysis (CSIA) is used to evaluate the extent of contaminant 51 remediation by quantifying isotope enrichment of one or more elements in the residual pollutant. ${ }^{27-}$

$52{ }^{32}$ Because changes in stable isotope ratios (e.g., $\left.{ }^{15} \mathrm{~N} /{ }^{14} \mathrm{~N},{ }^{13} \mathrm{C} /{ }^{12} \mathrm{C}\right)$ reflect reactions in which bond-

53 cleavage occurs, isotope fractionation is minimally affected by non-degradative processes (e.g.,

54 sorption, dilution, phase transfer), thus circumventing many of the challenges associated with

55 monitoring pollutant removal by concentration measurements alone. ${ }^{33,34}$ Despite the incorporation

56 of CSIA into published monitored natural attenuation protocols, the majority of efforts have

57 focused on biodegradation..$^{21,27,28,35-37}$

58 The recent emergence of 2,4-dinitroanisole (DNAN) in insensitive munitions formulations has

59 caused concern because of its potential to contaminate large areas of land and water. ${ }^{38,39} \mathrm{We}$

60 previously provided the first assessment of $\mathrm{C}$ and $\mathrm{N}$ isotope fractionation during abiotic DNAN

61 reduction ${ }^{40}$ but did not consider reductants beyond synthetic Fe-minerals. The Fe(II)-mediated

62 reduction of DNAN generated isotope fractionation patterns that were indicative of certain reaction 
63 pathways yet independent of DNAN reaction rates and solution chemistry (e.g., organic matter). ${ }^{40}$

64 Given the heterogeneity of natural soils and sediments and the crystallographic diversity of Fe-

65 minerals, however, it remains to be understood if DNAN isotope fractionation during reduction by

$66 \mathrm{Fe}(\mathrm{II})$ of natural minerals deviates from that observed with synthetic analogs. Because multiple

67 amendments of a given reductant are often required to achieve remediation targets with

68 ISCR, ${ }^{12,41,42}$ it is similarly unknown how multiple redox cycles will affect the interpretation of

69 CSIA results. Our findings suggest that because DNAN reduction by mineral-associated Fe(II)

70 follows a common reaction pathway (i.e., abiotic nitro-group reduction ${ }^{28,35,40,43-45}$ ), the associated

71 isotope fractionation will not be affected despite the use of synthetic minerals or naturally collected

72 ferruginous soils and sediments. This understanding could allow for DNAN to be a surrogate for

73 other nitroaromatic compounds (NACs) including 2,4,6-trinitrotoluene (TNT) and analogs of

74 nitrobenzene in the subsurface ${ }^{46}$ and is important given the continuing need for in situ remediation

75 techniques. ${ }^{47}$ Numerous studies have indeed reported similar isotope enrichment factors from the

76 abiotic reduction of several NACs in a range of experimental laboratory systems. ${ }^{43-45}$

77 In this study, we explored the application of CSIA for monitoring DNAN reduction during

78 dithionite-based ISCR schemes. Sodium dithionite $\left(\mathrm{Na}_{2} \mathrm{~S}_{2} \mathrm{O}_{4}\right)$ was chosen as the reductant because

79 of its previous success for pollutant remediation in contaminated aquifers. ${ }^{11,19,41,48}$ We tested the

80 reactivity of several Fe-bearing minerals and Fe-mineral containing sediments to promote DNAN

81 reduction in batch reactors receiving amendments of aqueous $\mathrm{Fe}(\mathrm{II})$ and those receiving ISCR and

82 used the distributions of reaction products to track the number of reduction equivalents transferred.

83 The $\mathrm{N}$ and $\mathrm{C}$ isotope fractionation was measured during batch experiments to determine the bulk

84 isotope enrichment factors $\left(\varepsilon_{\mathrm{N}}\right.$ and $\left.\varepsilon_{\mathrm{C}}\right)$ and apparent kinetic isotope effects $\left({ }^{15} \mathrm{~N}-\mathrm{AKIE}\right.$ and ${ }^{13} \mathrm{C}$ -

85 AKIE) associated with DNAN reduction. To simulate reducing environmental conditions, 
86 subsurface materials collected from two field sites were exposed to DNAN following ISCR in

87 continuous-flow column reactors. A modified Rayleigh equation was used to make quantitative 88 estimates of DNAN degradation from $\mathrm{N}$ isotope ratios $\left(\delta^{15} \mathrm{~N}\right)$ measured during each experiment.

89 The accuracy of this approach was evaluated by conducting statistical comparisons of predicted 90 versus observed extent of DNAN degradation.

\section{MATERIALS AND METHODS}

93 A complete list of chemicals used in this study is provided in the Supporting Information (SI).

94 Laboratory conditions. All syntheses and batch experiments were performed in an anaerobic 95 chamber (Coy Laboratory Products Inc.) with a 95\% $\mathrm{N}_{2} / 5 \% \mathrm{H}_{2}$ atmosphere. Column experiments 96 were performed in a NexGen anaerobic glovebox (Vacuum Atmospheres Company) maintained 97 at $<1 \mathrm{ppm} \mathrm{O}_{2}$ with $\mathrm{N}_{2}$ balance. Ultrapure water $(\geq 18.2 \mathrm{M} \Omega \cdot \mathrm{cm})$ was generated by a Milli-Q 98 Academic system (MilliporeSigma) and used to prepare all aqueous solutions. The ultrapure water 99 was purged with $\mathrm{N}_{2}$ gas $(99.99 \%$, Matheson) for at least $2 \mathrm{~h}$ prior to transfer into the chamber. 100 Methanolic stock solutions were similarly prepared in deoxygenated methanol (ACS grade, 101 MilliporeSigma). Laboratory equipment and reagents were evacuated in the exchange chamber 102 and equilibrated overnight in the glovebag before use.

103 Material preparation and characterization. Subsurface materials were collected from the 104 Twin Cities Army Ammunition Plant (TCAAP; Arden Hills, MN) and the Tinker Air Force Base 105 (Tinker AFB; Oklahoma City, OK). Both sites have a history of contamination by organic 106 pollutants and have required remediation efforts. ${ }^{1,49}$ Aquifer material from TCAAP was collected 107 from the saturated zone by sonic drilling to a depth of $41-45 \mathrm{~m}$. The material was dried, purged 108 with $\mathrm{N}_{2}$ gas, and stored inside the anaerobic chamber. Shallow sediment collected from Tinker 
109 AFB was dried at $100{ }^{\circ} \mathrm{C}$ and stored in an amber jar under laboratory atmosphere. Both TCAAP 110 and Tinker AFB materials were sieved by particle size to $350-425 \mu \mathrm{m}$ before use. Synthetic 111 magnetite nanoparticles were obtained from our previous work $^{40}$ and a suspension of 112 rhombohedral hematite in deoxygenated, ultrapure water $(\sim 15 \mathrm{~g} / \mathrm{mL})$ was acquired from Voelz et 113 al. ${ }^{50}$

114 Each material was characterized by X-ray diffraction (XRD; Figure S1) to evaluate the purity 115 (synthetic minerals) and bulk mineralogy (natural materials). No additional peaks were detected 116 in patterns collected from synthetic minerals. The primary Fe-bearing phase as detectable by XRD 117 in natural materials was magnetite $\left(\mathrm{Fe}_{3} \mathrm{O}_{4} \text {; TCAAP }\right)^{1,51}$ and hematite $\left(\mathrm{Fe}_{2} \mathrm{O}_{3}\right.$; Tinker AFB). Quartz $118\left(\mathrm{SiO}_{2} ; \mathrm{PDF} \# 46-1045\right)$ was detected in each collected material as expected for highly weathered 119 systems.

120 The total iron content $\left(\mathrm{Fe}_{\mathrm{T}}\right)$ of TCAAP and Tinker AFB materials was quantified by inductively 121 coupled plasma optical emission spectroscopy (ICP-OES). The ratio of $\mathrm{Fe}(\mathrm{II}) / \mathrm{Fe}(\mathrm{III})$ was 122 estimated by acid dissolution in $3 \mathrm{M} \mathrm{HCl}^{52,53}$ and quantification by the ferrozine method ${ }^{54}$ (Section $123 \mathrm{~S} 3$ ). The amount of ion-exchangeable Fe(II) was estimated by saturating each material in $1 \mathrm{M}$ $124 \mathrm{CaCl}_{2}$ for $7 \mathrm{~d}$ and was below the limit of quantification in all samples (data not shown). ${ }^{55}$ The 125 magnetic portion of the TCAAP sediment (hereafter termed "TCAAP extract") was separated from 126 the bulk material with a neodymium magnet as described by Strehlau et al. ${ }^{51}$ and characterized by 127 the same analyses. A summary of the relevant chemical and physical properties of all materials is 128 provided in Table S1. Additional characterizations of hematite ${ }^{50}$ and magnetite ${ }^{51}$ are reported 129 elsewhere.

130 In situ chemical reduction. For batch experiments receiving ISCR treatment, Fe-bearing 131 materials were suspended in a solution of $\mathrm{K}_{2} \mathrm{CO}_{3} / \mathrm{S}_{2} \mathrm{O}_{4}{ }^{2-}(2: 1 \mathrm{~mol} / \mathrm{mol})$ and rotated for $24 \mathrm{~h}$, at 
132 which point the suspension was separated via centrifugation and the supernatant discarded. The 133 dithionite concentrations were selected so that enough dithionite was added to theoretically reduce 134 one-tenth of the total Fe present (i.e., $1 \mathrm{~mol} \mathrm{~S}_{2} \mathrm{O}_{4}{ }^{2-}: 20 \mathrm{~mol} \mathrm{Fe}$; see eq 1). The $\mathrm{K}_{2} \mathrm{CO}_{3} / \mathrm{S}_{2} \mathrm{O}_{4}{ }^{2-}$ ratio 135 was chosen to buffer the 4 moles of $\mathrm{H}^{+}$released per 1 mole of dithionite consumed during iron 136 reduction (eq 1$)$.

$$
\mathrm{S}_{2} \mathrm{O}_{4}^{2-}+2 \mathrm{Fe}^{3+}+2 \mathrm{H}_{2} \mathrm{O} \rightarrow 2 \mathrm{Fe}^{2+}+2 \mathrm{SO}_{3}^{2-}+4 \mathrm{H}^{+}
$$

138 The treated materials were then washed three times with carbonate buffer $(10 \mathrm{mM}, \mathrm{pH} 7)$ by 139 centrifugation to remove excess dithionite and its reaction products (e.g., sulfate, sulfite, 140 thiosulfate), ${ }^{11}$ suspended in carbonate buffer, and immediately used for DNAN reduction 141 experiments in batch reactors. The Fe(II) content of each reduced material after ISCR was 142 determined by acid dissolution as described above.

143 For column experiments, the materials were conditioned before adding dithionite by passing 144 carbonate buffer $(10 \mathrm{mM}, \mathrm{pH} 7.0)$ upwards through the column at $0.5 \mathrm{~mL} / \mathrm{min}$ for 5 pore volumes. 145 An aqueous solution of $1.25 \mathrm{mM}$ sodium dithionite and $2.50 \mathrm{mM} \mathrm{K}_{2} \mathrm{CO}_{3}(\mathrm{pH} 8-9)$ was then fed 146 upward to the column at $0.25 \mathrm{~mL} / \mathrm{min}$ for $\sim 18-20 \mathrm{~h}$. The low flow rate and long run $(\sim 30$ pore 147 volumes) time were used to allow enough time for the reaction to occur. Columns were flushed 148 with $\sim 10$ pore volumes of carbonate buffer to remove unreacted dithionite and any oxidized sulfur 149 species. The exact amounts of pore volumes were chosen so that the same total amount of 150 dithionite:Fe was introduced to each system (see eq 1). The total amount of iron in each column 151 was in 20-fold excess to the dithionite added (i.e., $1 \mathrm{~mol} \mathrm{~S}_{2} \mathrm{O}_{4}{ }^{2-}: 20 \mathrm{~mol} \mathrm{Fe}_{\mathrm{T}}$ ) to target a reduction 152 of one-tenth of $\mathrm{Fe}_{\mathrm{T}}$. Anoxic dithionite-buffer solutions were prepared fresh before each experiment 153 to avoid loss of dithionite by aqueous disproportion; the rate of dithionite loss by aqueous 154 disproportionation, however, has shown to be slower than Fe(III) reduction by dithionite. ${ }^{19}$ 
155 Batch experiments. Batch reactors were prepared in $35 \mathrm{~mL}$ borosilicate serum bottles according

156 to previously described procedures. ${ }^{40}$ First, a suspension of an untreated or dithionite-reduced Fe-

157 bearing mineral in $10 \mathrm{mM}$ carbonate buffer $(\mathrm{pH} 7.0)$ was added to each reactor. Solid loadings

158 were varied from $1.0 \mathrm{~g} / \mathrm{L}$ (hematite) to $143 \mathrm{~g} / \mathrm{L}$ (TCAAP) such that DNAN transformation occurred

159 in a similar time period. Aqueous $\mathrm{Fe}(\mathrm{II})$ was added to a concentration of $1 \mathrm{mM}$ in reactors

160 containing untreated materials. The dithionite-reduced materials did not receive amendments of

$161 \mathrm{Fe}(\mathrm{II})$. Reactors were equilibrated for $21-24 \mathrm{~h}$ on an end-over-end rotator (Glas-col) at $40 \mathrm{rpm}$ at

162 which point the $\mathrm{pH}$ and aqueous Fe(II) concentration (via the Ferrozine assay; ${ }^{54}$ Section S3) were

163 measured. If necessary, the $\mathrm{pH}$ was adjusted back to 7.0 with $1 \mathrm{M} \mathrm{HCl}$ or $1 \mathrm{M} \mathrm{NaOH}$ and the

164 aqueous $\mathrm{Fe}(\mathrm{II})$ content was restored to $1 \mathrm{mM}$ in the reactors to which $\mathrm{Fe}(\mathrm{II})$ was added. Reactions

165 were initiated by spiking DNAN from a methanolic stock solution to an initial concentration of

$166200 \mu \mathrm{M}$. Reactors were placed on the rotator $(40 \mathrm{rpm})$ and sacrificed at appropriate time points for

167 concentration and stable isotope analyses. The $\mathrm{pH}$ (all reactors) and $\mathrm{Fe}(\mathrm{II})$ concentrations (Fe(II)

168 amended reactors only) were closely monitored during reactions and maintained at 7.0 and $1 \mathrm{mM}$,

169 respectively. Reactions were quenched by filtration through a $0.2 \mu$ m nylon syringe filter (Chrom

170 Tech) and stabilized with $1 \mathrm{M} \mathrm{HCl}$ (trace metals grade, MilliporeSigma) to $\mathrm{pH}<4$ to prevent iron

171 precipitation; DNAN did not react with aqueous Fe(II) under these conditions (data not shown). A

172 portion $(\sim 1 \mathrm{~mL})$ of each sample was analyzed for DNAN and intermediate/product concentrations

173 by high pressure liquid chromatography (HPLC; method in SI) and the remaining sample $(\sim 18$

$174 \mathrm{~mL}$ ) was stored at $4{ }^{\circ} \mathrm{C}$ for CSIA of DNAN.

175 The quantity of reduction equivalents transferred to DNAN from each reduced material was 176 calculated with the assumption that 6 moles of electrons are required to reduce one nitro-moiety 177 to the corresponding amine (see Scheme S1). The reduced products typically generated during 
178 abiotic DNAN reduction are 2-amino-4-nitroanisole (2-ANAN), 4-amino-2-nitroanisole (4179 ANAN), and 2,4-diaminoanisole (DAAN). Thus, 6 and 12 electrons are required for each mole of cm I.D., $10 \mathrm{~cm}$ length) were packed with each natural material to uniform bulk $\left(\rho_{\mathrm{b}}=1.66 \pm 0.04\right.$

$\left.183 \mathrm{~g} / \mathrm{cm}^{3}\right)$ and particle densities $\left(\rho_{\mathrm{p}}=2.68 \pm 0.05 \mathrm{~g} / \mathrm{cm}^{3}\right)$. The mean porosity of sediment columns 184 was $0.44 \pm 0.05$ (see Table S2). A flow adapter (Kimble) with fluorinated ethylene propylene 185 (FEP) tubing was secured to the column inlet to prevent sediment migration and facilitate accurate 186 bed height calculations. A polypropylene end cap was fixed at the column outlet. All feed solutions 187 were amended with $10 \mathrm{mM} \mathrm{NaCl}$ to prevent the precipitation of insoluble species which may cause 188 changes to flow characteristics. Pore volume and porosity were determined by saturating with 10 $189 \mathrm{mM} \mathrm{NaCl}$ and a step input conservative tracer $(100 \mathrm{mM} \mathrm{NaBr})$ was used to characterize column 190 flow and estimate the dispersion coefficient (Table S2; fitting details in SI). Bromide 191 concentrations at the column outlet were measured with a conductivity probe (Oakton). Dispersion 192 coefficients prior to experiments were $2.38 \pm 0.24$ and $2.53 \pm 0.12 \mathrm{~cm}^{2} \mathrm{~s}^{-1}$ for TCAAP and Tinker 193 AFB columns, respectively, at a flow rate of $0.5 \mathrm{~mL} / \mathrm{min}$. All column materials were then reduced 194 by sodium dithionite before experiments using DNAN.

195 Columns were equilibrated prior to DNAN reduction experiments by upward flow $(0.5 \mathrm{~mL} / \mathrm{min})$ 196 with $10 \mathrm{mM}$, pH 7.0 carbonate buffer including $10 \mathrm{mM} \mathrm{NaCl}$ for 5 pore volumes. Reactions were 197 initiated by adding DNAN $(200 \mu \mathrm{M})$ to the feed solution and collecting effluent samples with an 198 automated fraction collector (Bio-Rad Laboratories Inc). Experiments were terminated once the 199 effluent concentration was equal to that of the feed solution. Columns were then flushed with 200 carbonate buffer for several pore volumes to remove residual DNAN and any reaction products. 
201 The column materials were then reduced again by sodium dithionite according to the method 202 described above before further experiments using DNAN. The total number of reduction 203 equivalents transferred to DNAN were calculated by integrating the concentrations of 2/4-ANAN 204 and DAAN measured in the effluent (eq S2).

205 Compound specific isotope analysis. ${ }^{13} \mathrm{C} /{ }^{12} \mathrm{C}$ and ${ }^{15} \mathrm{~N} /{ }^{14} \mathrm{~N}$ isotope ratios of DNAN were 206 measured following previously established procedures for gas chromatography / isotope ratio mass 207 spectrometry (GC/IRMS) and solid phase micro extraction (SPME arrow) and are detailed in the 208 Supporting Information. ${ }^{40,56-59}$ Isotope signatures were calculated from isotope ratios according to 209 eq S4 relative to Vienna PeeDee Belemnite $\left(\delta^{13} \mathrm{C}_{\mathrm{VPDB}}\right)$ and air $\left(\delta^{15} \mathrm{~N}_{\text {air }}\right)$ reference standards. ${ }^{60}$

210 Carbon and nitrogen isotope enrichment factors $\left(\varepsilon_{C}, \varepsilon_{N}\right)$ were calculated by non-linear regression 211 of $\mathrm{C}$ and $\mathrm{N}$ isotope signatures $\left(\delta^{13} \mathrm{C}, \delta^{15} \mathrm{~N}\right)$ vs the fraction of remaining substrate $\left(c / c_{0}\right)$ as shown 212 in eq $2 .{ }^{59}$

$$
\frac{\delta^{\mathrm{h}} \mathrm{E}+1}{\delta^{\mathrm{h}} \mathrm{E}_{0}+1}=\left(\frac{\mathrm{c}}{\mathrm{c}_{0}}\right)^{\varepsilon_{\mathrm{E}}}
$$

214 where $\delta^{\mathrm{h}} \mathrm{E}_{0}$ is the initial isotope ratios of DNAN $\left(\delta^{13} \mathrm{C}_{0}=-37.4 \pm 0.1 \%\right.$, $\delta^{15} \mathrm{~N}_{0}=-2.4 \pm 0.1 \%$ ) as

215 evaluated by elemental analysis (EA)/IRMS. Apparent kinetic isotope effects $\left({ }^{13} \mathrm{C}-\mathrm{AKIE},{ }^{15} \mathrm{~N}-\right.$

216 AKIE) were determined from eq 3 based on the methods outlined by Elsner et al. ${ }^{61}$

$$
{ }^{\mathrm{h}} \mathrm{E}-\mathrm{AKIE}=\frac{1}{1+\mathrm{n}^{*} \varepsilon_{\mathrm{E}}}
$$

218 where $\mathrm{n}$ is a correction for isotopic dilution $\left(\mathrm{n}=2\right.$ for primary ${ }^{15}$ N-AKIEs and $\mathrm{n}=1$ for secondary $219{ }^{13} \mathrm{C}$-AKIEs). A linear regression of $\mathrm{N}$ and $\mathrm{C}$ isotope signatures was used to evaluate two220 dimensional isotope fractionation trends. The slope of this regression $\left(\Lambda^{\mathrm{N} / \mathrm{C}}\right)$ was calculated using 221 both a simple linear regression model and the York method described by Ojeda et al. ${ }^{62}$ and is 222 approximately equal to the ratio of the bulk isotope enrichment factors $\left(\varepsilon_{N} / \varepsilon_{C}\right)$. Because values of 
$223 \Lambda^{\mathrm{N} / \mathrm{C}}$ from our previous work ${ }^{40}$ were calculated by simple linear regression, in this report the result 224 of the York method is provided as an additional reference.

225 To estimate the extent of DNAN transformation $(F)$ during column experiments, measurements 226 of $\delta^{15} \mathrm{~N}$ at the breakthrough front were applied to a modified form of the Rayleigh fractionation 227 equation (eq 4$)^{27}$ using an $\varepsilon_{\mathrm{N}}$ that was calculated based on the results of multiple datasets. This 228 combined $\varepsilon_{\mathrm{N}}$ value $\left(\varepsilon_{\mathrm{N}}{ }^{*}\right)$ was obtained by plotting all $\delta^{15} \mathrm{~N}$ measurements $(\mathrm{n}=122)$ from batch 229 experiments of DNAN reduction in this study and in Berens et al. ${ }^{40}$ and performing a non-linear 230 regression of the combined data according to eq 2. The extent of DNAN reduction was calculated 231 with eq 4 from the deviation of measured $\delta^{15} \mathrm{~N}$ values from $\delta^{15} \mathrm{~N}_{0}$. using the combined $\varepsilon_{\mathrm{N}}{ }^{*}$ value.

232 Note that eq 4 is the result of a reorganization of eq 2 to account for $\varepsilon_{N}{ }^{*}$. We evaluated the accuracy

233 of our estimates by performing a linear regression of the predicted vs measured values of $c / c_{0}$ and 234 calculating the mean absolute error (MAE) of the predictions (eq 5).

$$
\begin{gathered}
F=\frac{c}{c_{0}}=\left(\frac{\delta^{15} \mathrm{~N}+1}{\delta^{15} \mathrm{~N}_{0}+1}\right)^{1 / \varepsilon_{\mathrm{N}}^{*}} \\
\mathrm{MAE}=\frac{\sum_{\mathrm{i}=1}^{\mathrm{n}}\left|\left(c / c_{0, \text { measured }}\right)_{\mathrm{i}}-\left(c / c_{0, \text { predicted }}\right)_{\mathrm{i}}\right|}{\mathrm{n}}
\end{gathered}
$$

\section{RESULTS AND DISCUSSION}

239 Kinetic studies in batch reactors. Reduction of DNAN occurred in all reactors receiving

240 amendments of aqueous Fe(II) (Figure 1a, open symbols) or ISCR by sodium dithionite (Figure

241 1a, closed symbols). DNAN reduction was not observed in reactors containing only untreated

242 minerals or aqueous $\mathrm{Fe}(\mathrm{II})$ alone (Figure S2). This supports the current understanding that $\mathrm{Fe}$ (II)-

243 surface associations are required to mediate contaminant, ${ }^{2,63-67}$ and in particular DNAN, ${ }^{40}$

244 reduction. The transformation products detected during DNAN reduction were 2-ANAN, 4- 
ANAN, and DAAN (Figure 1b). X-ray diffraction (XRD) patterns collected before and after ISCR

246 showed no detectable changes in mineral composition following the treatments (Figure S1) which

247 suggests that the primary effect of ISCR on the structures of hematite and magnetite was the 248 generation of surface-associated Fe(II) from oxide-Fe(III).
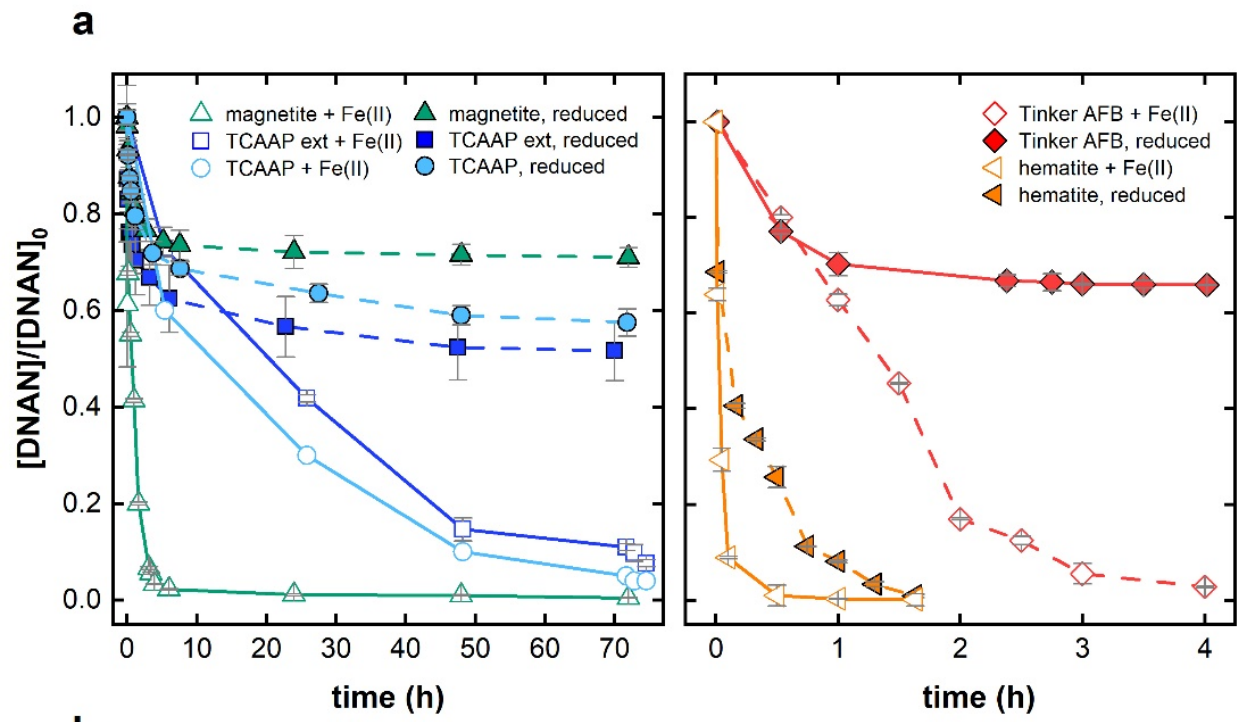

\section{b}

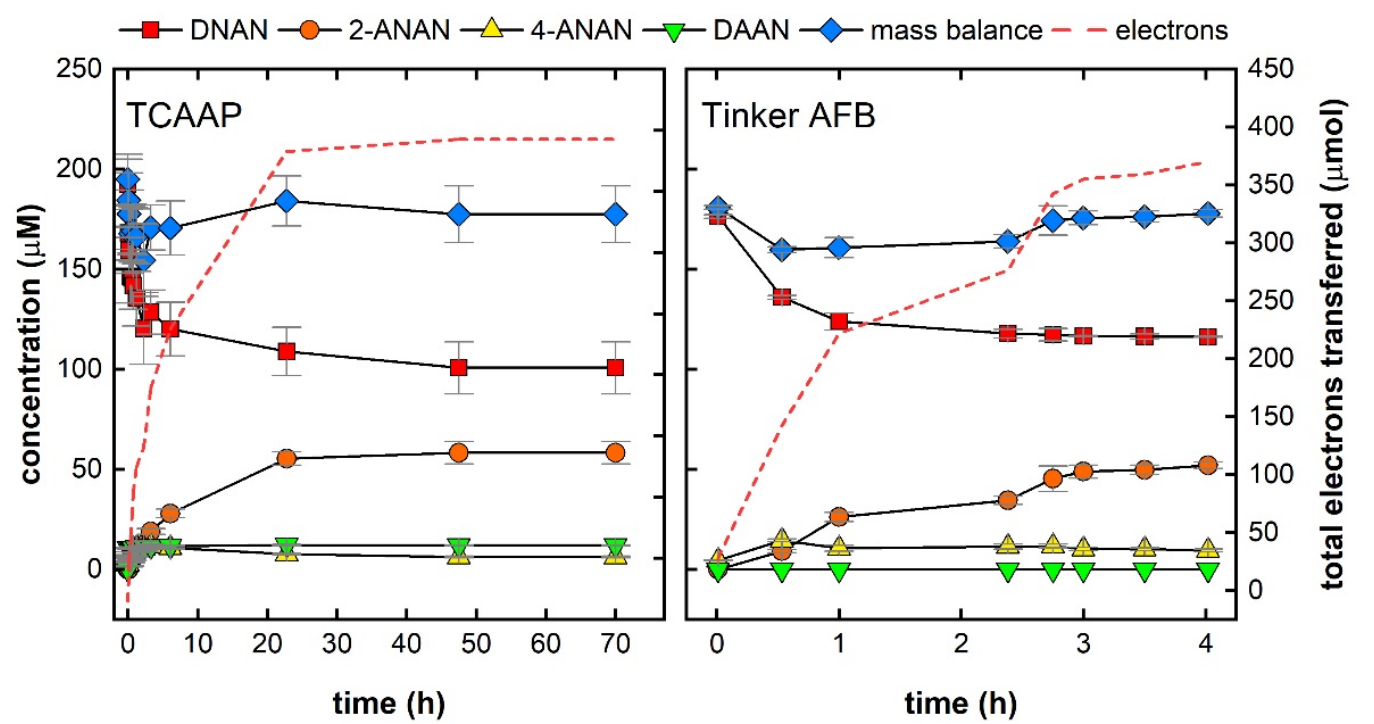

time (h)

250 Figure 1. (a) Concentrations of DNAN during abiotic reduction by natural (TCAAP and Tinker 251 AFB) and synthetic Fe-bearing (magnetite and hematite) materials. Experiments were performed 252 with either untreated materials in the presence of $1 \mathrm{mM}$ aqueous $\mathrm{Fe}(\mathrm{II})$ (open symbols) or with 253 dithionite-reduced materials without additional Fe(II) (closed symbols). (b) Concentrations of 254 DNAN, 2-ANAN, 4-ANAN, DAAN, and the cumulative number of electrons transferred during 
DNAN reduction by reduced TCAAP (left) and Tinker AFB (right) materials. All error bars represent standard deviations of triplicate reactors. Note the difference in time scales.

When aqueous $\mathrm{Fe}(\mathrm{II})$ was maintained $(1 \mathrm{mM})$ throughout the batch experiments, all of the added DNAN was reduced to $2 / 4$-ANAN or subsequently DAAN by each of the untreated minerals

260 (Figure 1a, open symbols). In reactors receiving ISCR, only a portion of the DNAN was removed

261 (Figure 1a, closed symbols), likely because of a limited supply of available electron equivalents 262 (i.e., mineral-associated Fe(II)) generated during ISCR. To understand the extent of DNAN 263 reduction in systems receiving ISCR, an electron balance was computed for each set of reactions

264 (Figure 1b, dashed line). Accounting for the number of electrons transferred to DNAN as a

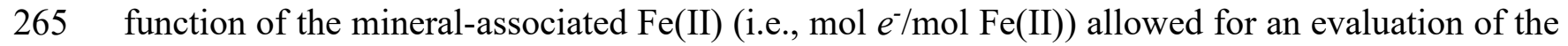
266 efficiency of ISCR to generate reactive Fe(II).

267 Dithionite-reduced magnetite, TCAAP extract, and hematite promoted DNAN reduction with 268 extents of electron transfer ranging from $0.359-0.603 \mathrm{~mol} e^{-/} / \mathrm{mol} \mathrm{Fe}(\mathrm{II})$ (Table 1). These results 269 suggest that not all available iron $\left(\mathrm{Fe}_{\mathrm{T}}\right)$ was reduced to reaction-accessible $\mathrm{Fe}(\mathrm{II})^{68}$ during ISCR.

270 The washing of materials following dithionite treatments may have caused the release of $\mathrm{Fe}(\mathrm{II})$

271 that was not retained on mineral surfaces. It is also possible that potentially reducible oxide-Fe(III) 272 was inaccessible to dithionite. ${ }^{69-72}$

273 The lower standard reduction potential $\left(E_{\mathrm{H}}{ }^{0}\right)$ of hematite/Fe(II) $(+0.793$ V) versus 274 magnetite/ $\mathrm{Fe}(\mathrm{II})(+1.053 \mathrm{~V})^{73}$ may further explain the difference in electron transfer between the 275 two systems. The reactivity of Fe-bearing minerals for pollutant reduction increases with lower $E_{\mathrm{H}}$ 276 values as evidenced by hematite experiments. Moreover, magnetite stoichiometry $(x=$ $277 \mathrm{Fe}(\mathrm{II}) / \mathrm{Fe}(\mathrm{III}))$ directly correlates with its intrinsic $E_{\mathrm{H}}$ values $^{74}$ and reactivity towards NAC 278 reduction. ${ }^{75}$ The magnetite used in this study ranged from partially oxidized $(x=0.1$, TCAAP 
279 extract) to fully reduced, stoichiometric $(x=0.5$, synthetic magnetite $)$ materials. Low

280 stoichiometry magnetite is a better oxidant and was thus more easily reduced by dithionite than

281 the high stoichiometry magnetite (Table S1). These results emphasize the potential benefits of

282 ISCR to magnetite-bearing soils and sediments in which partially oxidized magnetite is common

283 and may be amenable to ISCR leading to more stoichiometric and thus reactive magnetite. ${ }^{76,77}$

285 Table 1. Total iron $\left(\mathrm{Fe}_{\mathrm{T}}\right)$ and $\mathrm{Fe}(\mathrm{II})$ content of materials after dithionite treatments, and the 286 cumulative number electrons transferred during DNAN reduction experiments.

\begin{tabular}{|c|c|c|c|c|}
\hline system & $\begin{array}{c}\mathrm{Fe}_{\mathrm{T}} \\
(\mu \mathrm{mol})\end{array}$ & $\begin{array}{l}\mathrm{Fe}(\mathrm{II}) \\
(\mu \mathrm{mol})^{c}\end{array}$ & $\begin{array}{c}\text { total } e^{-} \text {transferred } \\
(\mu \mathrm{mol})^{d, e}\end{array}$ & $\operatorname{mol} e^{-/ m o l ~ F e(I I) ~}$ \\
\hline \multicolumn{5}{|l|}{ batch } \\
\hline TCAAP & $3430^{a}$ & 170 & $393 \pm 1$ & $2.31 \pm 0.01$ \\
\hline TCAAP extract & $865^{a}$ & 432 & $232 \pm 1$ & $0.536 \pm 0.003$ \\
\hline magnetite & $903^{b}$ & 451 & $162 \pm 0.3$ & $0.359 \pm 0.001$ \\
\hline Tinker AFB & $2180^{a}$ & 79.1 & $370 \pm 0.4$ & $4.68 \pm 0.01$ \\
\hline hematite & $439^{b}$ & 219 & $132 \pm 1$ & $0.603 \pm 0.006$ \\
\hline \multicolumn{5}{|l|}{ column } \\
\hline TCAAP & $25800^{a}$ & 1280 & $183 \pm 30$ & $0.143 \pm 0.022$ \\
\hline Tinker AFB & $17000^{a}$ & 616 & $109 \pm 10$ & $0.176 \pm 0.020$ \\
\hline
\end{tabular}

${ }^{a}$ Determined by ICP-OES. ${ }^{b}$ Calculated from structural formulas of pure minerals. ${ }^{c}$ Calculated by acid dissolution and quantification by the ferrozine method. ${ }^{54}$ Calculated using eqs S1-2. ${ }^{e}$ Uncertainties represent standard deviations of triplicate reactors.

The number of reduction equivalents transferred to DNAN from dithionite-reduced TCAAP

the initial amount of Fe(II) present after dithionite treatments (Table 1). Despite targeted dithionite

291 dosages to reduce one-tenth of the $\mathrm{Fe}_{\mathrm{T}}$, the calculated reduction efficiencies (i.e., $\mathrm{Fe}(\mathrm{II}) / \mathrm{Fe}_{\mathrm{T}}$ from

292 data in Table 1) of TCAAP and Tinker AFB materials during ISCR were only $4.95 \%$ and $3.62 \%$,

293 respectively. The low reduction efficiencies suggest that other reducible moieties were present in

294 the natural materials which were reduced by dithionite and subsequently provided reducing

295 equivalents for DNAN reduction. ${ }^{78,79}$ For example, the reversible transfer of electrons in the 
296 environment is often mediated by natural organic matter and humic substances, specifically those 297 containing quinone moeities ${ }^{80-83}$, and the TCAAP and Tinker materials contained $0.46 \%(\mathrm{w} / \mathrm{w})$ 298 and $0.88 \%(\mathrm{w} / \mathrm{w})$ organic matter, respectively. The electron-carrying capacity of these species 299 plays a key role in both the reduction of substituted nitrobenzenes ${ }^{84}$ and ferric iron. ${ }^{85}$ Another 300 possibility is that acid digestion of the materials to determine Fe(II) was incomplete. This is 301 especially likely in materials with high Si content, such as phyllosilicates, because the Fe(III) is 302 easily reduced by dithionite but $\mathrm{Fe}(\mathrm{II})$ extraction requires a rigorous treatment with $\mathrm{H}_{2} \mathrm{SO}_{4}$ and 303 HF. ${ }^{68,86,87}$ This fraction of $\mathrm{Fe}(\mathrm{II})$ is a known strong reductant of NACs. ${ }^{3,88}$ The prominence of $\mathrm{SiO}_{2}$ 304 (Figure S1) and low $\mathrm{Fe}_{\mathrm{T}}$ content of TCAAP and Tinker AFB materials (Table S1) suggests that a 305 large share of $\mathrm{Fe}_{\mathrm{T}}$ was associated with silicates.

306 Reactions in packed columns. To probe for the availability of reduction equivalents in flow307 through systems, DNAN $(200 \mu \mathrm{M})$ was introduced to column reactors containing dithionite308 reduced TCAAP or Tinker AFB materials for five cycles of $\mathrm{Fe}(\mathrm{III})$ reduction by dithionite 309 followed by DNAN exposure (Figure 2a-b). As shown in Figures 2c-d, ISCR in column reactors 310 generated reaction-accessible electron equivalents in natural materials and promoted the reductive 311 transformation of DNAN with a similar product distribution to the batch experiments (Figures 1c$312 \mathrm{~d}$, Figure S3). It should be noted that DAAN concentrations exceeded the input DNAN 313 concentration (up to $150 \%$ ) during the early stages of experiments. To assess this phenomenon, 314 the cumulative amount of DAAN measured in the column effluent was compared to the total 315 amount of DNAN introduced. We found that the amount of DAAN in the peaks did not exceed the 316 total amount of DNAN introduced to the columns. This indicated that DAAN was either associated 317 with or retained on mineral surfaces and was then displaced by another solute, namely DNAN or 


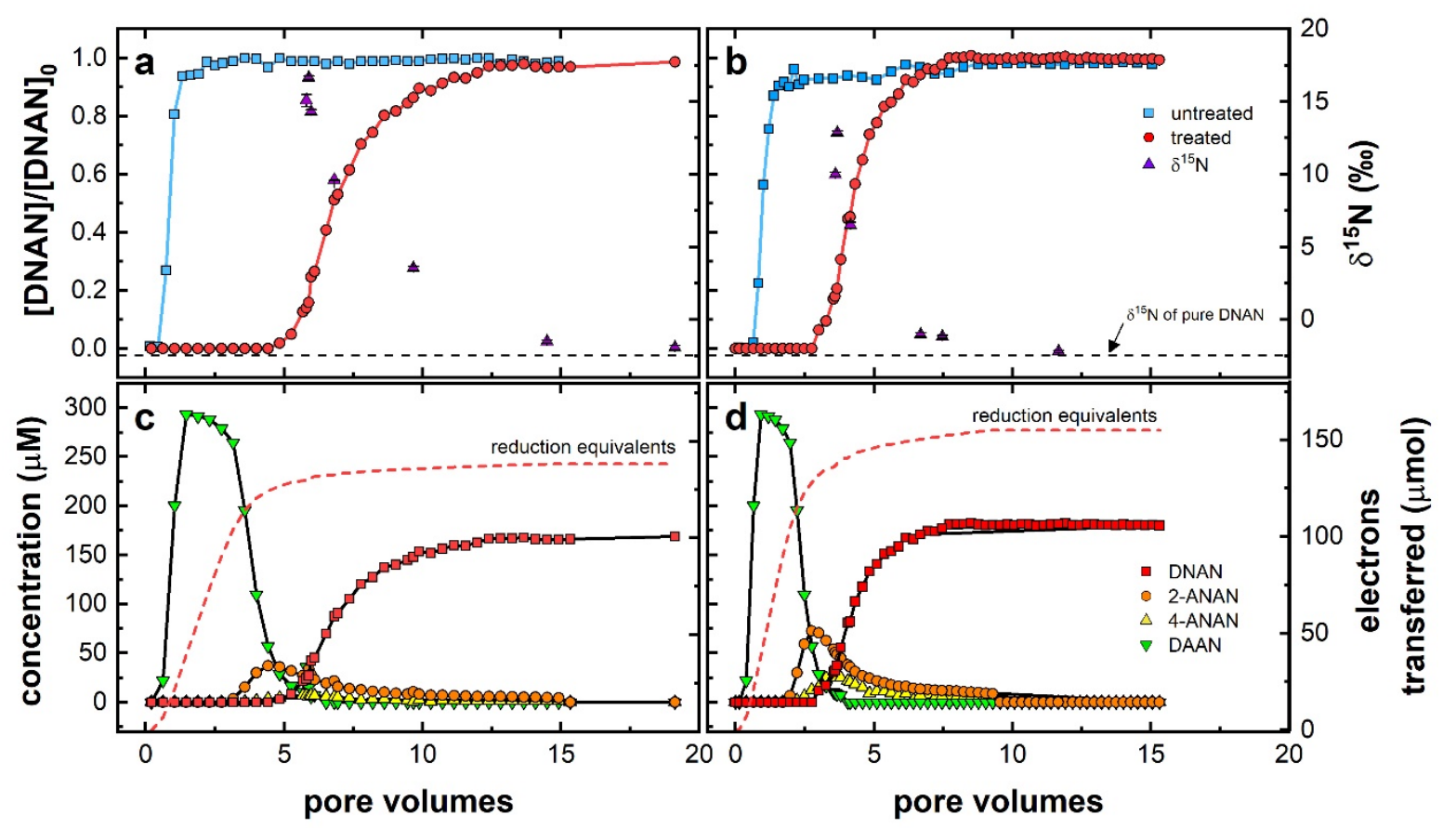

Figure 2. Breakthrough curves for $200 \mu \mathrm{M}$ DNAN in (a) TCAAP and (b) Tinker AFB packed columns before (squares) and after (circles) receiving ISCR. Triangles denote measurements of $\delta^{15} \mathrm{~N}$ of DNAN in the effluent from treated columns. Error bars denote standard deviations from five sequential breakthrough experiments. Aqueous concentrations of DNAN (circles), 2-ANAN (squares), 4-ANAN (triangles), and DAAN (diamonds) during DNAN exposure to (c) TCAAP and (d) Tinker AFB columns. Dashed lines represent the cumulative number of reduction equivalents transferred to DNAN during experiments. The data provided in panels $\mathrm{c}$ and $\mathrm{d}$ are a representation of one of the reduction-reaction cycles shown in panels a and b, respectively. Individual cycles are shown in Figure S3.

332 the solution displaced DAAN from the surface. Such competition and effluent concentrations

333 exceeding influents have been observed for ion sorption on activated carbon. ${ }^{89}$ Another possible

334 explanation is that a reaction intermediate (e.g., a hydroxylamine) is more strongly retained by the

335 solid phase, as previously observed during the reduction of cyanonitrobenzene, ${ }^{90}$ and the excess 
337 Despite ISCR targets that were equivalent to batch experiments (i.e., $10 \%$ reduction of $\mathrm{Fe}_{\mathrm{T}}$ ), the 338 extent of electron transfer to DNAN from the reduced materials was markedly lower in columns 339 than in batch experiments $\left(0.143 \pm 0.022\right.$ and $0.176 \pm 0.020 \mathrm{~mol} e^{-} / \mathrm{mol} \mathrm{Fe}(\mathrm{II})$ for TCAAP and 340 Tinker AFB columns, respectively; Table 1). This suggests that either (i) reactive Fe(II) was 341 removed from the column, (ii) the transport of dithionite or DNAN to mineral surfaces was 342 restricted by conditions within the column, or (iii) the extent of mineral reduction was affected by 343 the rate of dithionite decomposition.

344 Flow-through systems introduce the potential for newly generated Fe(II) or other reducible 345 species to be removed from the column before association with mineral surfaces or pollutant 346 reduction occurs. Monitoring aqueous Fe(II) in column effluents, however, negligible losses of 347 Fe(II) from the column were observed during and after exposure to dithionite (Figure S4). Only $348 \quad 1.6$ and $5.3 \mu \mathrm{mol}$ Fe(II) in TCAAP columns and 2.6 and $4.0 \mu \mathrm{mol} \mathrm{Fe(II)} \mathrm{in} \mathrm{Tinker} \mathrm{AFB} \mathrm{columns}$ 349 were removed during the first and fifth exposures to dithionite, respectively, corresponding to $350 \quad 0.06-0.20 \%(\mathrm{w} / \mathrm{w})$ of $\mathrm{Fe}_{\mathrm{T}}$. This suggests that $\mathrm{Fe}(\mathrm{II})$ generated during ISCR was mostly retained 351 within the column either because it was not released from the mineral surfaces or it was effectively 352 adsorbed by or bound within the materials within the column. The presence of silicates may also 353 indicate a portion of $\mathrm{Fe}(\mathrm{II})$ that is not readily removed from natural soils and sediments. The 354 consistency of breakthrough curves during the five cycles of ISCR and DNAN exposure (Figures 355 S3) indicates that the removal of reduction equivalents by column flow likely did not affect the 356 potential for contaminant reduction.

357 It is also possible that the transport of reducing equivalents or pollutants to mineral surfaces is 358 restricted in confined systems composed of heterogenous media. ${ }^{91}$ Moreover, the iron content of 359 natural sediments can be distributed throughout the bulk mineral as opposed to being concentrated 
360 at singly-coordinated oxygen atoms on mineral surfaces, leaving Fe(III) inaccessible to dithionite.

361 To account for these potential limitations, the columns in this study were packed to a uniform

362 porosity $(0.44 \pm 0.05)$, bulk density $\left(1.66 \pm 0.04 \mathrm{~g} \mathrm{~cm}^{-3}\right)$, and particle density $\left(2.68 \pm 0.05 \mathrm{~g} \mathrm{~cm}^{-3}\right)$

363 to resemble typical subsurface conditions in sandy soils similar to the TCAAP and Tinker AFB

364 (Table S2). ${ }^{69}$ The dispersion coefficients in TCAAP $\left(2.37 \pm 0.22 \mathrm{~cm}^{2} \mathrm{~s}^{-1}\right)$ and Tinker AFB $(2.53 \pm$

$36512 \mathrm{~cm}^{-2} \mathrm{~s}^{-1}$ ) columns were also determined and indicated advection-dominated regimes with

366 negligible effects from flow retardation. ${ }^{92}$ Column porosities and dispersion coefficients were

367 remeasured following all experiments and were not appreciably different from the initial values

368 (Table S2), indicating that ISCR did not affect the physical properties of columns or restrict

369 material transport.

370 Lastly, the decomposition of dithionite can unevenly distribute iron reduction by ISCR in

371 columns. In batch reactors, the entire supply of dithionite was simultaneously exposed to all of the

372 solid material in a well-mixed heterogenous suspension, whereas, in columns only the materials

373 located immediately following the inlet were exposed to unreacted dithionite. Because dithionite

374 undergoes rapid disproportionation in aqueous media, the combination of Fe(III) reduction and

375 dithionite decomposition limits mineral reduction at locations away from the point of

376 application. $^{11,48}$ These differences explain the difference between the batch and column

377 experiments and provide an explanation for the lower extent of DNAN reduction in the column.

$379{ }^{15} \mathbf{N}$ fractionation during DNAN reduction. DNAN reduction in batch reactors introduced

380 strong ${ }^{15} \mathrm{~N}$ enrichment in the remaining contaminant with variations in magnitude comparable to

381 those observed in earlier studies (Figure 3). ${ }^{15} \mathrm{~N}$ isotope enrichment factors, $\varepsilon_{\mathrm{N}}$, ranged from -11.1

$382 \pm 4.3 \%$ to $-21.5 \pm 2.6 \%$ corresponding to ${ }^{15} \mathrm{~N}$-AKIEs of $1.023 \pm 0.009$ to $1.045 \pm 0.005$ (eq. 3 ). 
383 Because no bonds to $\mathrm{C}$ atoms are involved during the reactions leading to nitro-group reduction,

$384 \mathrm{C}$ isotope fractionation was small and resulted in secondary ${ }^{13} \mathrm{C}$-AKIE values $(1.0005 \pm 0.0002)$.

385 These results are typical for nitro-group reduction on NACs by Fe(II) species associated with 386 minerals (i.e., large ${ }^{15} \mathrm{~N}-\mathrm{AKIE}=1.030-1.045$ and ${ }^{13} \mathrm{C}-\mathrm{AKIE}$ close to unity). ${ }^{43-45,74}$ The variability

387 of isotope effects is related to uncertainties associated with experimental and data evaluation

388 procedures such as a different number of samples with variable extent of reactant conversion

389 included in the regression analysis. ${ }^{59}$ We postulate these effects as the likely sources of variation

390 in $\varepsilon_{\mathrm{N}}$ values reported for experiments with reduced sediments (Figure 3). In fact, our previous

391 report of DNAN reduction by iron (oxyhydr)oxides revealed $\varepsilon_{\mathrm{N}}$ values between $-9 \pm 2 \%$ and -19

$392 \pm 1 \%$ corresponding to ${ }^{15} \mathrm{~N}$-AKIEs of $1.018 \pm 0.002$ and $1.039 \pm 0.001$, respectively, as well as

393 the small $\varepsilon_{\mathrm{C}}$ and ${ }^{13} \mathrm{C}$-AKIE values that are consistent with previous studies. ${ }^{40}$ The kinetics of

394 electron and proton transfers preceding the isotope sensitive step of aromatic nitro-group reduction

395 could also lead to variation of ${ }^{15} \mathrm{~N}-\mathrm{AKIE}$ through partially masking of the isotopically sensitive

396 bond cleavage reaction(s $)^{45,74,93}$ and smaller ${ }^{15} \mathrm{~N}$-AKIEs were found with increasing rates of NAC

397 reduction. ${ }^{45}$ However, no such trends were observed in our studies with DNAN (Table S3) and 398 further investigation of this phenomenon is beyond the scope of this work.

399 The agreement in combined ${ }^{15} \mathrm{~N}$ - and ${ }^{13} \mathrm{C}$-AKIEs between this and other reports of abiotic NAC 400 reduction ${ }^{43-45}$ suggests that DNAN reduction followed the same reaction mechanism (i.e., nitro401 group reduction) in the presence of Fe(II)-amended synthetic and natural materials and with the 402 naturally collected materials after ISCR. Dual-element isotope analysis $\left(\delta^{15} \mathrm{~N}\right.$ vs $\left.\delta^{13} \mathrm{C}\right)$ was used to 403 support this interpretation by illustrating the distinction of our results from other known DNAN 404 transformation pathways (Figure S5). ${ }^{57}$ For example, the correlation slope $\left(\Lambda^{\mathrm{N} / \mathrm{C}}\right.$ ) calculated from 405 this study was $43.8 \pm 28.6\left(38.9 \pm 4.3\right.$ calculated based on Ojeda et al. $\left.{ }^{62}\right)$ which is in clear contrast 
with independent evidence from biodegradation $\left(\Lambda^{\mathrm{N} / \mathrm{C}}=0.87 \pm 0.15\right)$ and alkaline hydrolysis $\left(\Lambda^{\mathrm{N} / \mathrm{C}}\right.$ $=0.46 \pm 0.04$ ) experiments. ${ }^{57}$ We previously reported a similar $\Lambda^{\mathrm{N} / \mathrm{C}}$ of $50.5 \pm 23.2$ during $\mathrm{Fe}(\mathrm{II})$ mediated DNAN reduction by synthetic iron (oxyhydr)oxides. ${ }^{40}$

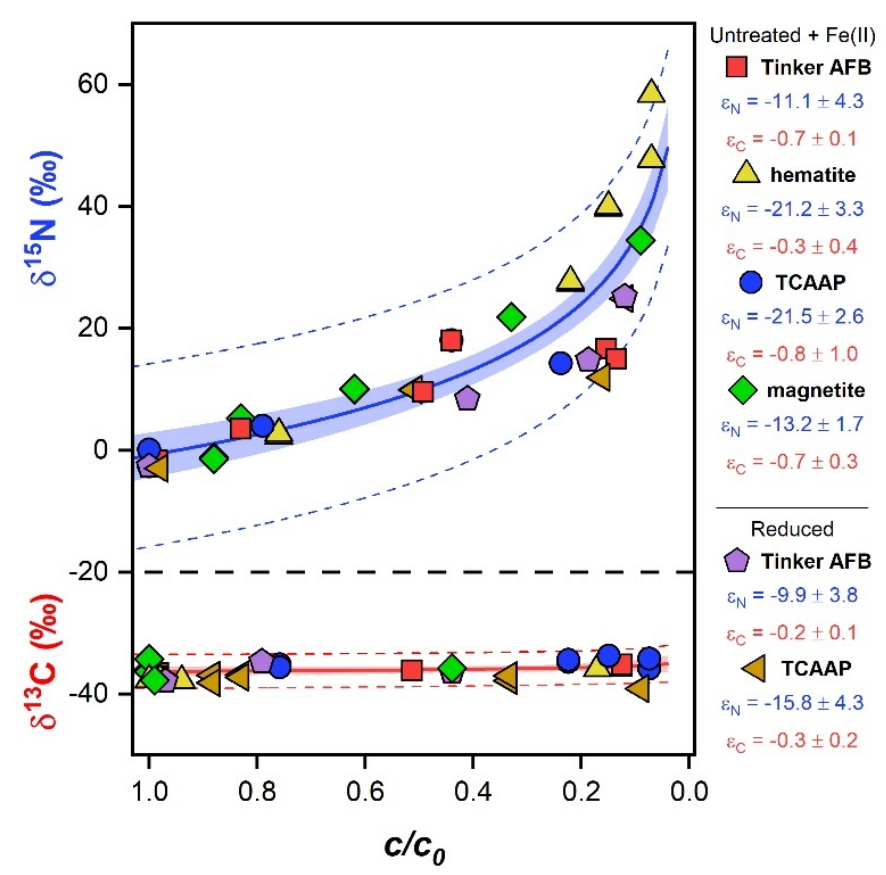

411 Figure 3. Nitrogen $\left(\delta^{15} \mathrm{~N}\right)$ and carbon $\left(\delta^{13} \mathrm{C}\right)$ isotope signatures vs fraction of remaining substrate $412\left(c / c_{0}\right)$ during DNAN reduction by iron-bearing minerals. Solid lines represent fits from nonlinear 413 regression with shaded portions indicating the $95 \%$ confidence intervals. Dashed lines designate $41495 \%$ prediction intervals. $\mathrm{N}$ and $\mathrm{C}$ isotope enrichment factors $\left(\varepsilon_{\mathrm{N}}, \varepsilon_{\mathrm{C}}\right)$ were determined from non415 linear regression of the data points for each mineral type. Data are shown for untreated materials 416 in the presence of $\mathrm{Fe}(\mathrm{II})$ and dithionite-treated materials.

419 shown in Figures $2 \mathrm{a}-\mathrm{b}, \delta^{15} \mathrm{~N}$ values of DNAN at the breakthrough front ( $\sim 5$ pore volumes) were 420 isotopically enriched in ${ }^{15} \mathrm{~N}$ corresponding to an increase of $\delta^{15} \mathrm{~N}$ by $15-20 \%$. Measured values

421 subsequently decreased and approached the value for unreacted DNAN $(-2.4 \pm 0.1 \%$ as the 422 effluent concentrations approached the input level. This trend of $\delta^{15} \mathrm{~N}$ is consistent with the elution 423 of an increasing share of DNAN that has not been reduced by surface-associated Fe(II). While the 
424 data provide evidence that ISCR promoted DNAN reduction, it should be noted that $\delta^{15} \mathrm{~N}$ values 425 were not fully restored to the input $\delta^{15} \mathrm{~N}$ value $(-1.9 \pm 0.1 \%$ and $-2.2 \pm 0.1 \%$ in columns with 426 TCAAP and Tinker AFB sediment, respectively) suggesting the retention and slow release of 427 enough residual ${ }^{15} \mathrm{~N}$-enriched DNAN from the mineral surfaces to influence the $\delta^{15} \mathrm{~N}$ after the 428 reaction capacity was exhausted or residual, low level transformation activity. ${ }^{94-96}$

429 Based on the above reasoning for the variability of $\mathrm{N}$ isotope fractionation associated with NAC 430 reduction, we aggregated all of our current data ${ }^{40}$ for isotope fractionation during Fe(II)-catalyzed 431 DNAN reduction in batch experiments. The combined $\mathrm{N}$ isotope ratio measurements resulted in 432 an averaged $\varepsilon_{\mathrm{N}}{ }^{*}$ value of $-14.9 \pm 1.3 \%$, which is based on one of the most comprehensive data sets 433 for the stable $\mathrm{N}$ isotope fractionation related to the transformation of a single nitroaromatic 434 contaminant (Figure S6a). This value was used to establish a quantitative relationship of $c / c_{0}$ vs $435 \Delta^{15} \mathrm{~N}$ (Figure S6b) to estimate the amount of DNAN degradation from $\delta^{15} \mathrm{~N}$ measurements made 436 during column experiments (Figure $2 \mathrm{a}-\mathrm{b})$. Values of $\varepsilon_{\mathrm{N}}$ calculated from TCAAP $(-8.6 \pm 1.8 \%$ ) and 437 Tinker AFB (-7.2 $\pm 0.8 \%$ ) column experiments were lower than batch experiments which could 438 indicate longitudinal mixing with unreacted DNAN in the feed solution. This interpretation agrees 439 with systematic evaluations of the applicability of eq. 2 to assess contaminant transformation in 440 groundwater plumes, ${ }^{97}$ where physical heterogeneity, geometry of the contaminant plume, and the 441 extent of degradation can lead to an underestimation of isotope enrichment factors.

442 Application of the higher average $\varepsilon_{\mathrm{N}}{ }^{*}$ value of $-14.9 \pm 1.3 \%$ from batch experiments for the 443 evaluation of the extent of DNAN reduction in the sediment columns from the $\Delta^{15} \mathrm{~N}$ of DNAN 444 leads to predicted values that differ from the actual extent of conversion (Figure 4). A linear 445 regression of predicted versus measured quantities showed a correlation slope of $1.27 \pm 0.18\left(\mathrm{r}^{2}=\right.$ 446 0.96). By not forcing the regression through zero, predicted values overestimate the extent of 
447 conversion at high $c / c_{0}$ and underestimate conversion at low $c / c_{0}$. While the mean absolute error

448 (MAE) is $0.091 \pm 0.063$ in $c / c_{0}$, the inset in Figure 4 reveals that the relative error is greater at

449 larger conversions and illustrates that in our laboratory model system, the accuracy of the

450 assessment of the extent of degradation decreases with increasing turnover of the contaminant.

451 That said, underprediction of the extent of conversion at low $c / c_{0}$ provides a margin of safety.

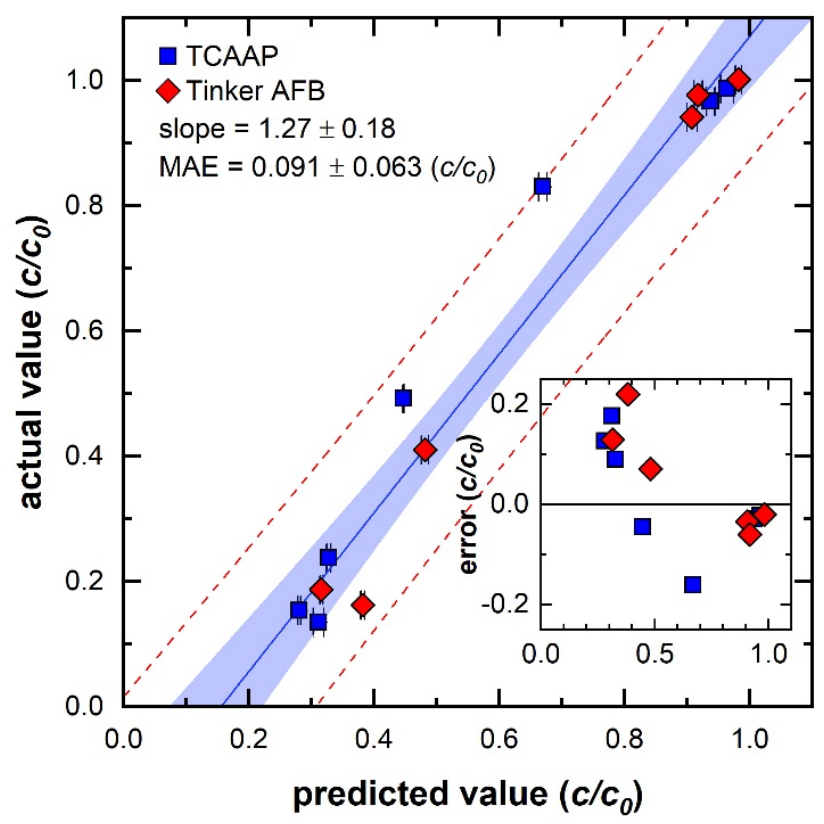

454 Figure 4. Predicted versus measured values of DNAN transformation by chemically reduced 455 TCAAP and Tinker AFB materials in column reactors. Predictions were made according to eq 2 456 using an $\varepsilon_{\mathrm{N}}{ }^{*}$ value of $-14.9 \%$. The solid line indicates the calculated fit by linear regression. Shaded 457 portions indicate $95 \%$ confidence intervals of linear regressions and dashed lines represent the $45895 \%$ prediction intervals. The inset shows the prediction error of each estimate.

460 While a number of additional factors pertinent to the hydrology of the contaminated subsurface 461 will contribute to the successful application of CSIA, ${ }^{98}$ Figure 4 illustrates that under the 462 assumption that the same reaction is occurring, there is a basis for using the $\mathrm{N}$ isotope fractionation 463 of DNAN measured during laboratory experiments as a proxy of transformation in the field. To 464 confirm the specificity of our model to $\mathrm{N}$ isotope fractionation associated with DNAN reduction, 
465 we also measured the accompanying $\delta^{13} \mathrm{C}$ values of DNAN to the $\delta^{15} \mathrm{~N}$ data shown in Figure 2a-

466 b. The observed minimal $\mathrm{C}$ isotope fractionation of DNAN at the breakthrough front $\left(\Delta^{13} \mathrm{C}<\sim 3 \%\right.$;

467 data in Figure S7) is in agreement with the postulated reduction reaction. Because this C isotope

468 fractionation was not observable after 6-7 pore volumes where $\mathrm{N}$ isotope fractionation continued,

469 we also consider it unlikely that another reaction such as concurrent (bio)degradation processes

470 contributed to our observations where $\mathrm{C}$ isotope fractionation would be more substantial based on

471 the reported $\varepsilon_{\mathrm{C}}$ of $-3 \%$ vs. $-0.3 \%$ shown in Figure $3 .{ }^{57}$ The distribution of $\delta^{13} \mathrm{C}$ against $\delta^{15} \mathrm{~N}$ from

472 column experiments also reflected the batch systems (Figures 3 and S5) and supports that, in both

473 cases, abiotic reduction was the primary reactive pathway. While we cannot exclude small

474 contributions of sorption processes to the observed DNAN isotope fractionation in dithionite

475 treated columns, data with untreated sediment (Figure S2) suggest that this process is of minor

476 importance.

477

478 Environmental significance. Our study investigated laboratory conditions and future work 479 should address direct applications of CSIA to contaminated field sites receiving ISCR. In addition, 480 to assess the efficiency of sediment reduction with external electron donors such as dithionite, 481 these analyses will have to include critical phenomena which we were not able to evaluate in a 482 laboratory model system. Several studies have shown that mass transport related processes 483 including diffusive isotope fractionation, hydrodynamic dispersion, multiple contaminant sources, 484 and the quality of stable isotope ratio measurements can lead to both over- and underestimations 485 of the extent of contaminant degradation. ${ }^{98-101}$ For ISCR, the understanding of the local 486 hydrogeology will be necessary to accurately estimate the extent of contaminant (bio)degradation 487 with CSIA. 
488 As remediation strategies are implemented, the adaptation of CSIA for pollutant monitoring in 489 treated soil, sediment, and groundwater is critical for its successful integration into protocols for 490 monitored natural attenuation and active remediation. To an extent, this has been accomplished

491 for the assessment of biodegradation of nitroaromatic explosives in soil. ${ }^{28}$ In this work, we reported 492 CSIA as a robust technique to quantify abiotic DNAN reduction in systems receiving repeated 493 dithionite treatments, but future work should include a survey of other in situ abiotic remediation 494 strategies (e.g., calcium polysulfides, ${ }^{13}$ sodium persulfate ${ }^{102}$ ). The observation that isotope 495 fractionation is unaffected by natural subsurface materials and ISCR can be leveraged to generate 496 accurate estimates of contaminant removal strengthen our findings. Moreover, it provides strong 497 support for the compulsory lines of evidence set by the US Environmental Protection Agency for 498 evaluating the progress of natural attenuation. ${ }^{27}$ Considering DNAN as a surrogate for other NACs 499 allows for this approach to be applied to a wide range of environmental pollutants. ACKNOWLEDGEMENTS

502 This work was supported by the Strategic Environmental Research and Development Program 503 (SERDP, Project No. ER2618). Thanks to Lee Penn (UMN, Department of Chemistry) for 504 allowing use of the X-ray diffractometer and to Jeanette L. Voelz (UMN, Department of 505 Chemistry) for providing the hematite nanoparticles used in this study. ICP-OES analyses were 506 performed by Clare Johnston (UMN, Department of Chemistry). 
ASSOCIATED CONTENT

\section{Supporting Information}

510 A detailed report of additional analytical methods, materials synthesis and characterization

511 techniques, batch reaction procedures, CSIA calculations, and further kinetics and isotope results.

512 The files are available free of charge via the internet at https://pubs.acs.org/journal/esthag.

513

514 The authors declare no competing interests.

\section{REFERENCES}

517 (1) Ferrey, M. L.; Wilkin, R. T.; Ford, R. G.; Wilson, J. T. Nonbiological Removal of Cis518 Dichloroethylene and 1,1-Dichloroethylene in Aquifer Sediment Containing Magnetite. Environ. 519 Sci. Technol. 2004, 38 (6), 1746-1752.

520 (2) Hofstetter, T. B.; Heijman, C. G.; Haderlein, S. B.; Holliger, C.; Schwarzenbach, R. P.

(3) Hofstetter, T. B.; Neumann, A.; Schwarzenbach, R. P. Reduction of Nitroaromatic Reducing Subsurface Conditions. Environ. Sci. Technol. 1999, 33 (9), 1479-1487.

(4) Hofstetter, T. B.; Schwarzenbach, R. P.; Haderlein, S. B. Reactivity of Fe(II) Species Associated with Clay Minerals. Environ. Sci. Technol. 2003, 37 (3), 519-528.

(5) Butler, E. C.; Hayes, K. F. Effects of Solution Composition and PH on the Reductive 
1276-1284.

531 (6) Schaefer, C. E.; Ho, P.; Berns, E.; Werth, C. Mechanisms for Abiotic Dechlorination of Trichloroethene by Ferrous Minerals under Oxic and Anoxic Conditions in Natural Sediments. Environ. Sci. Technol. 2018, 52 (23), 13747-13755.

(7) Simpanen, S.; Dahl, M.; Gerlach, M.; Mikkonen, A.; Malk, V.; Mikola, J.; Romantschuk,

M. Biostimulation Proved to Be the Most Efficient Method in the Comparison of in Situ Soil Remediation Treatments after a Simulated Oil Spill Accident. Environ. Sci. Pollut. Res.

(8) McGuire, T. M.; Adamson, D. T.; Burcham, M. S.; Bedient, P. B.; Newell, C. J. Evaluation of Long-Term Performance and Sustained Treatment at Enhanced Anaerobic Bioremediation Sites. Groundw. Monit. Remediat. 2016, 36 (2), 32-44.

(9) Wu, Y.-J.; Liu, P.-W. G.; Hsu, Y.-S.; Whang, L.-M.; Lin, T.-F.; Hung, W.-N.; Cho, K.-C. Application of Molecular Biological Tools for Monitoring Efficiency of Trichloroethylene Remediation. Chemosphere 2019, 233, 697-704.

(10) Schaefer, C. E.; Lavorgna, G. M.; Haluska, A. A.; Annable, M. D. Long-Term Impacts on Groundwater and Reductive Dechlorination Following Bioremediation in a Highly

(11) Amonette, J. E.; Szecsody, J. E.; Schaef, H. T.; Templeton, J. C.; Gorby, Y. A.; Fruchter, J. Technology; Richland, WA, USA, 1994. 
551 (12) Fruchter, J. S. J. S.; Cole, C. R. C. R.; Williams, M. D. M. D.; Vermeul, V. R.; Amonette,

J. E. J. E.; Szecsody, J. E.; Istok, J. D.; Humphrey, M. D. Creation of a Subsurface

Permeable Treatment Zone for Aqueous Chromate Contamination Using In Situ Redox Manipulation. Groundw. Monit. Remediat. 2000, 20 (2), 66-77.

(13) Graham, M. C.; Farmer, J. G.; Anderson, P.; Paterson, E.; Hillier, S.; Lumsdon, D. G.;

Bewley, R. J. F. Calcium Polysulfide Remediation of Hexavalent Chromium Contamination from Chromite Ore Processing Residue. Sci. Total Environ. 2006, 364 (1-3), 32-44.

(14) Fan, D.; O’Brien Johnson, G.; G. Tratnyek, P.; L. Johnson, R. Sulfidation of Nano Zerovalent Iron (NZVI) for Improved Selectivity During In-Situ Chemical Reduction (ISCR). Environ. Sci. Technol. 2016, 50 (17), 9558-9565.

(15) Han, Y.; Yan, W. Reductive Dechlorination of Trichloroethene by Zero-Valent Iron Nanoparticles: Reactivity Enhancement through Sulfidation Treatment. Environ. Sci. Technol. 2016, 50 (23), 12992-13001.

(16) Niedźwiecka, J. B.; Finneran, K. T. Combined Biological and Abiotic Reactions with Iron and Fe(III)-Reducing Microorganisms for Remediation of Explosives and Insensitive Munitions (IM). Environ. Sci. Water Res. Technol 2015, 1, 34-39. Situ Chemical Reduction of Cr(VI) in Groundwater Using a Combination of Ferrous Sulfate and Sodium Dithionite: A Field Investigation. Environ. Sci. Technol. 2007, 41 (15), 52995305.

Dresel, P. E.; Wellman, D. M.; Cantrell, K. J.; Truex, M. T. Review: Technical and Policy 
Challenges in Deep Vadose Zone Remediation of Metals and Radionuclides. Environ. Sci. Technol. 2011, 45 (10), 4207-4216.

574

575

576

577

578

579

580

581

582

583

584

585

586

587

(19) Szecsody, J. E.; Fruchter, J. S.; Williams, M. D.; Vermeul, V. R.; Sklarew, D. In Situ Chemical Reduction of Aquifer Sediments: Enhancement of Reactive Iron Phases and TCE Dechlorination. Environ. Sci. Technol. 2004, 38 (17), 4656-4663.

(20) Brown, R. A.; Mueller, J. G.; Seech, A.G.; Henderson, J. K.; Wilson, J. T. Interactions between biological and abiotic pathways in the reduction of chlorinated solvents. Remediation, 2009, 20 (1), 9-20.

(21) McKelvie, J. R.; Mackay, D. M.; de Sieyes, N. R.; Lacrampe-Couloume, G.; Sherwood Lollar, B. Quantifying MTBE Biodegradation in the Vandenberg Air Force Base Ethanol Release Study Using Stable Carbon Isotopes. J. Contam. Hydrol. 2007, 94 (3-4), 157-165.

(22) Chartrand, M.; Passeport, E.; Rose, C.; Lacrampe-Couloume, G.; Bidleman, T. F.; Jantunen, L. M.; Sherwood Lollar, B. Compound Specific Isotope Analysis of Hexachlorocyclohexane Isomers: A Method for Source Fingerprinting and Field Investigation of in Situ Biodegradation. Rapid Commun. Mass Spectrom. 2015, 29 (6), 505514.

(23) Bosma, T. N. P.; Middeldorp, P. J. M.; Schraa, G.; Zehnder, A. J. B. Mass Transfer Limitation of Biotransformation: Quantifying Bioavailability. Environ. Sci. Technol. 1997, $31(1), 248-252$.

(24) Torrent, J.; Schwertmann, U.; Barron, V. The Reductive Dissolution of Synthetic Goethite and Hematite in Dithionite. Clay Miner. 1987, 22 (3), 329-337. 
593 (25) Yang, L.; I. Steefel, C.; A. Marcus, M.; R. Bargar, J. Kinetics of Fe(II)-Catalyzed

(29) Meckenstock, R. U.; Morasch, B.; Griebler, C.; Richnow, H. H. Stable Isotope Fractionation

Hunkeler, D.; Meckenstock, R. U.; Lollar, B. S.; Schmidt, T. C.; Wilson, J. T. A Guide for Assessing Biodegradation and Source Identification of Organic Ground Water Contaminants Using Compound Specific Isotope Analysis (CSIA); Oklahoma, USA, 2008.

(28) Wijker, R. S.; Bolotin, J.; Nishino, S. F.; Spain, J. C.; Hofstetter, T. B. Using CompoundSpecific Isotope Analysis to Assess Biodegradation of Nitroaromatic Explosives in the Subsurface. Environ. Sci. Technol. 2013, 47 (13), 6872-6883.

(30) Sherwood Lollar, B.; Slater, G. F.; Sleep, B.; Witt, M.; Klecka, G. M.; Harkness, M.; Spivack, J. Stable Carbon Isotope Evidence for Intrinsic Bioremediation of Tetrachloroethene and Trichloroethene at Area 6, Dover Air Force Base. Environ. Sci. Technol. 2000, 35 (2), 261-269.

(31) Thullner, M.; Richnow, H. H.; Fischer, A. Characterization and Quantification of in Situ 613 Biodegradation of Groundwater Contaminants Using Stable Isotope Fractionation Analysis: 
614

615

616

617

618

619

620

621

622

623

624

625

626

627

628

629

630

631

632

633

634

Advantages and Limitations. In Environmental and Regional Air Pollution; Nova Science Publishers, 2009.

(32) Alvarez-Zaldívar, P.; Centler, F.; Maier, U.; Thullner, M.; Imfeld, G. Biogeochemical Modelling of in Situ Biodegradation and Stable Isotope Fractionation of Intermediate Chloroethenes in a Horizontal Subsurface Flow Wetland. Ecol. Eng. 2016, 90, 170-179.

(33) Elsner, M.; Zwank, L.; Hunkeler, D.; Schwarzenbach, R. P. A New Concept Linking Observable Stable Isotope Fractionation to Transformation Pathways of Organic Pollutants. Environ. Sci. Technol. 2005, 39 (18), 6896-6916.

(34) Schmidt, T. C.; Zwank, L.; Elsner, M.; Berg, M.; Meckenstock, R. U.; Haderlein, S. B. Compound-Specific Stable Isotope Analysis of Organic Contaminants in Natural Environments: A Critical Review of the State of the Art, Prospects, and Future Challenges. Anal. Bioanal. Chem. 2004, 378 (2), 283-300.

(35) Wijker, R. S.; Zeyer, J.; Hofstetter, T. B. Isotope Fractionation Associated with the Simultaneous Biodegradation of Multiple Nitrophenol Isomers by Pseudomonas Putida B2. Environ. Sci. Process. Impacts 2017, 19 (5), 775-784.

(36) Sherwood Lollar, B.; Slater, G.; Ahad, J.; Sleep, B.; Spivack, J.; Brennan, M.; MacKenzie, P. Contrasting Carbon Isotope Fractionation during Biodegradation or Trichloroethylene and Toluene: Implications for Intrinsic Bioremediation. Org. Geochem. 1999, 30, 813-820.

(37) Aeppli, C.; B. Hofstetter, T.; I. F. Amaral, H.; Kipfer, R.; P. Schwarzenbach, R.; Berg, M. Quantifying In Situ Transformation Rates of Chlorinated Ethenes by Combining Compound-Specific Stable Isotope Analysis, Groundwater Dating, And Carbon Isotope 
Mass Balances. Environ. Sci. Technol. 2010, 44 (10), 3705-3711.

636

637

638

639

640

641

642

643

644

645

646

647

648

649

650

651

652

653

654

655

(38) Dodard, S. G.; Sarrazin, M.; Hawari, J.; Paquet, L.; Ampleman, G.; Thiboutot, S.; Sunahara, G. I. Ecotoxicological Assessment of a High Energetic and Insensitive Munitions Compound: 2,4-Dinitroanisole (DNAN). J. Hazard. Mater. 2013, 262, 143-150.

(39) Johnson, M. S.; Eck, W. S.; Lent, E. M. Toxicity of Insensitive Munition (IMX) Formulations and Components. Propellants, Explos. Pyrotech. 2017, 42 (1), 9-16.

(40) Berens, M. J.; Ulrich, B. A.; Strehlau, J. H.; Hofstetter, T. B.; Arnold, W. A. Mineral Identity, Natural Organic Matter, and Repeated Contaminant Exposures Do Not Affect the Carbon and Nitrogen Isotope Fractionation of 2,4-Dinitroanisole during Abiotic Reduction. Environ. Sci. Process. Impacts 2019, 21, 51-62.

(41) Boparai, H. K.; Comfort, S. D.; Shea, P. J.; Szecsody, J. E. Remediating ExplosiveContaminated Groundwater by in Situ Redox Manipulation (ISRM) of Aquifer Sediments. Chemosphere 2008, 71 (5), 933-941.

(42) He, F.; Zhao, D.; Paul, C. Field Assessment of Carboxymethyl Cellulose Stabilized Iron Nanoparticles for in Situ Destruction of Chlorinated Solvents in Source Zones. Water Res. 2010, 44 (7), 2360-2370.

(43) Hofstetter, T. B.; Neumann, A.; Arnold, W. A.; Hartenbach, A. E.; Bolotin, J.; Cramer, C. J.; Schwarzenbach, R. P. Substituent Effects on Nitrogen Isotope Fractionation during Abiotic Reduction of Nitroaromatic Compounds. Environ. Sci. Technol. 2008, 42 (6), 19972003.

(44) Hartenbach, A.; Hofstetter, T. B.; Berg, M.; Bolotin, J.; Schwarzenbach, R. P. Using 
Nitrogen Isotope Fractionation to Assess Abiotic Reduction of Nitroaromatic Compounds. Environ. Sci. Technol. 2006, 40 (24), 7710-7716.

(45) Hartenbach, A. E.; Hofstetter, T. B.; Aeschbacher, M.; Sander, M.; Kim, D.; Strathmann, T. J.; Arnold, W. A.; Cramer, C. J.; Schwarzenbach, R. P. Variability of Nitrogen Isotope Fractionation during the Reduction of Nitroaromatic Compounds with Dissolved Reductants. Environ. Sci. Technol. 2008, 42 (22), 8352-8359.

(46) Pichtel, J. Distribution and Fate of Military Explosives and Propellants in Soil: A Review. Appl. Environ. Soil Sci. 2012, 2012 (2012).

(47) Albright, R. D. Cleanup of Chemical and Explosive Munitions - Locating, Identifying Contaminants, and Planning for Environmental Remediation of Land and Sea Military Ranges and Ordnance Dumpsites, 2nd ed.; William Andrew: Norwich, NY, USA, 2012.

(48) Istok, J. D.; Amonette, J. E.; Cole, C. R.; Fruchter, J. S.; Humphrey, M. D.; Szecsody, J. E.; Teel, S. S.; Vermeul, V. R.; Williams, M. D.; Yabusaki, S. B. In Situ Redox Manipulation by Dithionite Injection: Intermediate-Scale Laboratory Experiments. Ground Water 1999,

(49) Hocking, G.; Givens, M. A.; Thurman, C. M.; Lacko, C. M. Installation of Permeable Reactive Barrier at Tinker Air Force Base, Oklahoma City, Oklahoma. In 5th International Conference on Remediation of Chlorinated and Recalcitrant Compounds; Monterey, CA, 2006.

(50) Voelz, J.; Arnold, W. A.; Penn, R. L. Redox-Induced Nucleation and Growth of Goethite on Synthetic Hematite Nanoparticles. Am. Mineral. 2018, 103, 1021-1029. 
677 (51) Strehlau, J. H.; Berens, M. J.; Arnold, W. A. Mineralogy and Buffer Identity Effects on RDX Kinetics and Intermediates during Reaction with Natural and Synthetic Magnetite. Chemosphere 2018, 213, 602-609.

(52) Cornell, R. M.; Giovanoli, R. Acid Dissolution of Hematites of Different Morphologies. Clay Miner. 1993, 28 (2), 223-232.

(53) Cornell, R. M.; Giovanoli, R. Acid Dissolution of Akaganeite and Lepidocrocite: The Effect 683 on Crystal Morphology. Clays Clay Miner. 1988, 36 (5), 385-390.

(54) Viollier, E.; Inglett, P. W.; Hunter, K.; Roychoudhury, A. N.; Van Cappellen, P. The Ferrozine Method Revisited: Fe(II)/Fe(III) Determination in Natural Waters. Appl. Geochemistry 2000, 15 (6), 785-790.

(55) Sumner, M. E.; Miller, W. P. Cation Exchange Capacity and Exchange Coefficients. In Methods of Soil Analysis Part 3 - Chemical Methods; 1996; pp 1201-1229.

(56) Berg, M.; Bolotin, J.; Hofstetter, T. B. Compound-Specific Nitrogen and Carbon Isotope Analysis of Nitroaromatic Compounds in Aqueous Samples Using Solid-Phase Microextraction Coupled to GC/IRMS. Anal. Chem. 2007, 79 (6), 2386-2393.

Ulrich, B. A.; Palatucci, M.; Bolotin, J.; Spain, J. C.; Hofstetter, T. B. Different Mechanisms of Alkaline and Enzymatic Hydrolysis of the Insensitive Munition Component 2,4Dinitroanisole Lead to Identical Products. Environ. Sci. Technol. Lett. 2018, 5 (7), 456-461.

(58) Kremser, A.; Jochmann, M. A.; Schmidt, T. C. PAL SPME Arrow - Evaluation of a Novel Solid-Phase Microextraction Device for Freely Dissolved PAHs in Water. Anal. Bioanal. 
698

699

700

(59) Pati, S. G.; Kohler, H.-P. E.; Hofstetter, T. B. Characterization of Substrate, Cosubstrate, and Product Isotope Effects Associated with Enzymatic Oxygenations of Organic Compounds Based on Compound-Specific Isotope Analysis. In Methods in Enzymology; Elsevier Inc., 2017; Vol. 596, pp 291-329.

(60) Schimmelmann, A.; Albertino, A.; Sauer, P. E.; Qi, H.; Molinie, R.; Mesnard, F. Nicotine, Acetanilide and Urea Multi-Level 2H-, 13C- and 15N-Abundance Reference Materials for Continuous-Flow Isotope Ratio Mass Spectrometry. Rapid Commun. Mass Spectrom. 2009, $23(22), 3513-3521$.

(61) Elsner, M. Stable Isotope Fractionation to Investigate Natural Transformation Mechanisms of Organic Contaminants: Principles, Prospects and Limitations. J. Environ. Monit. 2010, $12(11), 2005-2031$.

(62) Ojeda, A. S.; Phillips, E.; Mancini, S. A.; Sherwood Lollar, B. Sources of Uncertainty in Biotransformation Mechanistic Interpretations and Remediation Studies Using CSIA. Anal. Chem. 2019, 91 (14), 9147-9153.

(63) G. B. Williams, A.; M. Scherer, M. Spectroscopic Evidence for Fe(II)-Fe(III) Electron Transfer at the Iron Oxide-Water Interface. Environ. Sci. Technol. 2004, 38 (18), 47824790.

(64) Klausen, J. J.; Tröber, S. P.; Haderlein, S. B.; Schwarzenbach, R. P.; Troeber, S. P.; Haderlein, S. B.; Schwarzenbach, R. P. Reduction of Substituted Nitrobenzenes by Fe(II) in Aqueous Mineral Suspensions. Environ. Sci. Technol. 1995, 29 (9), 2396-2404.

(65) Amonette, J. E.; Workman, D. J.; Kennedy, D. W.; Fruchter, J. S.; Gorby, Y. A. 
Dechlorination of Carbon Tetrachloride by Fe(II) Associated with Goethite. Environ. Sci. Technol. 2000, 34 (21), 4606-4613.

(66) Elsner, M.; Schwarzenbach, R. P.; Haderlein, S. B. Reactivity of Fe(II)-Bearing Minerals toward Reductive Transformation of Organic Contaminants. Environ. Sci. Technol. 2004, $38(3), 799-807$.

Fan, D.; J. Bradley, M.; W. Hinkle, A.; L. Johnson, R.; G. Tratnyek, P. Chemical Reactivity Probes for Assessing Abiotic Natural Attenuation by Reducing Iron Minerals. Environ. Sci. Technol. 2016, 50 (4), 1868-1876.

(68) Voelz, J. L.; Johnson, N. W.; Chun, C. L.; Arnold, W. A.; Penn, R. L. Quantitative 728 Dissolution of Environmentally Accessible Iron Residing in Iron-Rich Minerals: A Review. ACS Earth Sp. Chem. 2019, 3 (8), 1371-1392.

(69) Essington, M. E. Soil and Water Chemistry: An Integrative Approach, 2nd ed.; CRC Press, 2015.

Guo, H.; Barnard, A. S. Naturally Occurring Iron Oxide Nanoparticles: Morphology, Surface Chemistry and Environmental Stability. J. Mater. Chem. A 2013, 1 (January 2013), $27-42$.

(71) Schwertmann, U.; Cornell, R. M. Iron Oxides in the Laboratory: Preparation and Characterization, 2nd ed.; Wiley-VCH: Weinheim, 2000.

737 (72) Strehlau, J. H.; Toner, B. M.; Arnold, W. A.; Penn, R. L. Accessible Reactive Surface Area and Abiotic Redox Reactivity of Iron Oxyhydroxides in Acidic Brines. Geochim. Cosmochim. Acta 2017, 197, 345-355. 
740 (73) James, B. R.; Brose, D. A. Oxidation-Reduction Phenomena. In Handbook of Soil Science: Properties and Processes; CRC Press: Boca Raton, FL, 2012; pp 14-1-14-24.

(74) Gorski, C. A.; Nurmi, J. T.; Tratnyek, P. G.; Hofstetter, T. B.; Scherer, M. M. Redox Behavior of Magnetite: Implications for Contaminant Reduction. Environ. Sci. Technol. 2010, 44 (1), 55-60.

(75) Gorski, C. A.; Scherer, M. M. Influence of Magnetite Stoichiometry on FeII Uptake and Nitrobenzene Reduction. Environ. Sci. Technol. 2009, 43 (10), 3675-3680.

(76) Haggstrom, L.; Annersten, H.; Ericsson, T.; Wappling, R.; Karner, W.; Bjarman, S. Magnetic Dipolar and Electric Quadrupolar Effects on the Mossbauer Spectra of Magnetite above the Verwey Transition. Hyperfine Interact. 1977, 5 (1), 201-214.

(77) Vandenberghe, R. E.; Hus, J. J.; De Grave, E. Evidence from Mössbauer Spectroscopy of Neo-Formation of Magnetite/Maghemite in the Soils of Loess/Paleosol Sequences in China. Hyperfine Interact. 1998, 117 (1/4), 359-369.

(78) Wehrli, B.; Sulzberger, B.; Stumm, W. Redox Processes Catalyzed by Hydrous Oxide Surfaces. Chem. Geol. 1989, 78 (3-4), 167-179.

(79) Torrent, J.; Barron, V. Iron Oxides in Relation to the Colour of Mediterranean Soils. In Applied Study of Cultural Heritage and Clays; 2003; pp 377-386.

(80) Lovley, D. R.; Coates, J. D.; Blunt-Harris, E. L.; Phillips, E. J. P.; Woodward, J. C. Humic Substances as Electron Acceptors for Microbial Respiration. Nature 1996, 382, 445-448.

(81) Scott, D. T.; Mcknight, D. M.; Blunt-Harris, E. L.; Kolesar, S. E.; Lovley, D. R. Quinone Moieties Act as Electron Acceptors in the Reduction of Humic Substances by Humics- 
Reducing Microorganisms. Environ. Sci. Technol. 1998, 32 (19), 2984-2989.

762

763

764

765

766

767

768

769

770

771

772

773

774

775

776

777

778

779

780

781

(82) Lovley, D. R.; Fraga, J. L.; Coates, J. D.; Blunt-Harris, E. L. Humics as an Electron Donor for Anaerobic Respiration. Environ. Microbiol. 1999, 1 (1), 89-98.

(83) Ratasuk, N.; A. Nanny, M. Characterization and Quantification of Reversible Redox Sites in Humic Substances. Environ. Sci. Technol. 2007, 41 (22), 7844-7850.

(84) M. Dunnivant, F.; P. Schwarzenbach, R.; L. Macalady, D. Reduction of Substituted Nitrobenzenes in Aqueous Solutions Containing Natural Organic Matter. Environ. Sci. Technol. 1992, 26 (11), 2133-2141.

(85) Deiana, S.; Gessa, C.; Manunza, B.; Rausa, R.; Solinas, V. Iron(III) Reduction by Natural Humic Acids: A Potentiometric and Spectroscopic Study. Eur. J. Soil Sci. 1995, 46 (1), $103-108$.

(86) Beyer, M. E.; Bond, A. M.; McLaughlin, R. J. W. Simultaneous Polarographic Determination of Ferrous, Ferric, and Total Iron in Standard Rocks. Anal. Chem. 2002, 47 (3), 479-482.

(87) Haese, R. R.; Wallmann, K.; Dahmke, A.; Kretzmann, U.; Müller, P. J.; Schulz, H. D. Iron Species Determination to Investigate Early Diagenetic Reactivity in Marine Sediments. Geochim. Cosmochim. Acta 1997, 61 (1), 63-72.

(88) Neumann, A.; Hofstetter, T. B.; Lüssi, M.; Cirpka, O. A.; Petit, S.; Schwarzenbach, R. P. Assessing the Redox Reactivity of Structural Iron in Smectites Using Nitroaromatic Compounds As Kinetic Probes. Environ. Sci. Technol. 2008, 42 (22), 8381-8387.

(89) Erickson, A. J.; Gulliver, J. S.; Arnold, W. A.; Brekke, C.; Bredal, M. Abiotic Capture of 
Stormwater Nitrates with Granular Activated Carbon. Environ. Eng. Sci. 2016, 33 (5), 354363.

784

785

786

787

788

789

790

792

793

794

795

796

797

798

799

800

801

802

(90) Simon, R.; Colón, D.; L. Tebes-Stevens, C.; J. Weber, E. Effect of Redox Zonation on the Reductive Transformation of P-Cyanonitrobenzene in a Laboratory Sediment Column. Environ. Sci. Technol. 2000, 34 (17), 3617-3622.

(91) Freeze, R. A.; Cherry, J. A. Groundwater, 1st ed.; Prentice Hall, 1979.

(92) Gulliver, J. S. Introduction to Chemical Transport in the Environment; Cambridge University Press: Cambridge, 2007.

(93) Stewart, S. M.; Hofstetter, T. B.; Joshi, P.; Gorski, C. A. Linking Thermodynamics to Pollutant Reduction Kinetics by Fe2+ Bound Toiron Oxides. Environ. Sci. Technol. 2018, $52(10), 5600-5609$.

(94) Haderlein, S. B.; Weissmahr, K. W.; Schwarzenbach, R. P. Specific Adsorption of Nitroaromatic Explosives and Pesticides to Clay Minerals. Environ. Sci. Technol. 1996, 30 (2), 612-622.

(95) Arthur, J. D.; Mark, N. W.; Taylor, S.; Šimunek, J.; Brusseau, M. L.; Dontsova, K. M. Batch Soil Adsorption and Column Transport Studies of 2,4-Dinitroanisole (DNAN) in Soils. $J$. Contam. Hydrol. 2017, 199, 14-23.

(96) B. Haderlein, S.; P. Schwarzenbach, R. Adsorption of Substituted Nitrobenzenes and Nitrophenols to Mineral Surfaces. Environ. Sci. Technol. 1993, 27 (2), 316-326.

(97) Abe, Y.; Hunkeler, D. Does the Rayleigh Equation Apply to Evaluate Field Isotope Data in Contaminant Hydrogeology? Environ. Sci. Technol. 2006, 40 (5), 1588-1596. 
803 (98) Thullner, M.; Centler, F.; Richnow, H. H.; Fischer, A. Quantification of Organic Pollutant 804 Degradation in Contaminated Aquifers Using Compound Specific Stable Isotope Analysis - Review of Recent Developments. Org. Geochem. 2012, 42 (12), 1440-1460.

(99) Chiogna, G.; Eberhardt, C.; Grathwohl, P.; A. Cirpka, O.; Rolle, M. Evidence of Compound-Dependent Hydrodynamic and Mechanical Transverse Dispersion by Multitracer Laboratory Experiments. Environ. Sci. Technol. 2009, 44 (2), 688-693. Applicability of Stable Isotope Fractionation Analysis for the Characterization of Benzene Biodegradation in a BTEX-Contaminated Aquifer. Environ. Sci. Technol. 2007, 41 (10), 3689-3696.

(101) Thullner, M.; Fischer, A.; Richnow, H. H.; Wick, L. Y. Influence of Mass Transfer on Stable Isotope Fractionation. Applied Microbiology and Biotechnology. Springer January 11, 2013, pp 441-452. Oxidation of Contaminated Soil and Groundwater Using Persulfate: A Review. Crit. Rev. Environ. Sci. Technol. 2010, 40 (1), 55-91. 


\section{TOC Art}

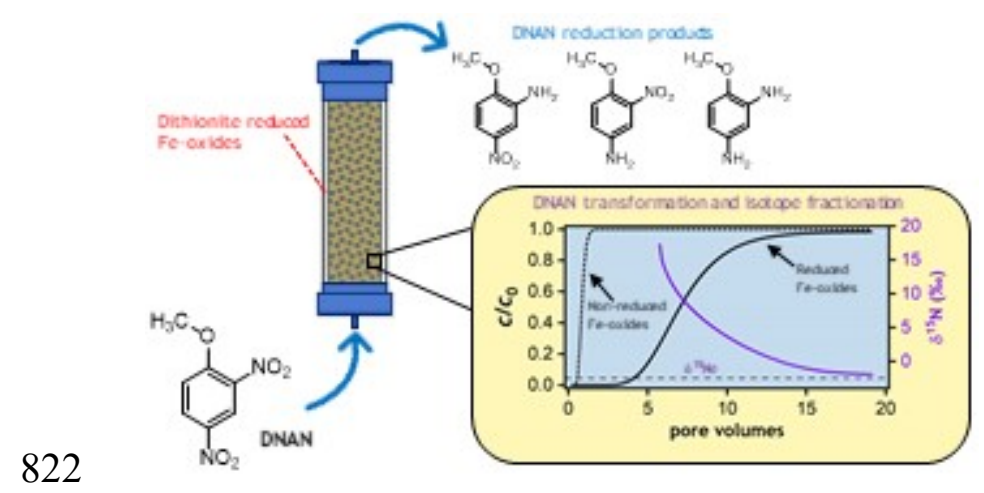

